\title{
Mongolia's assertive and pragmatic role in India's Connect Central Asia Policy: Current trajectory and Future Ahead
}

\author{
Subhash Kumar ${ }^{1}$, Souvik Chatterjee ${ }^{{ }^{*}}$ \\ ${ }^{1}$ Department of Politics and International Relations, Central University of Jharkhand, Jharkhand 835205, India
}

Article Info

Received: Jul 05, 2021

Revised: Jul 17, 2021

Accepted: Jul 31, 2021

Keywords:

Asia; China; India;

Mongolia:

Correspondent:

Souvik Chatterjee

Department of Politics and

International Relations, Central

University of Jharkhand.

Email:

chatterjeesouvik101@gmail.co $\mathrm{m}$

How to Cite:

Kumar, S. \& Chatterjee, S. (2021). Mongolia's assertive and pragmatic role in India's Connect Central Asia Policy: Current trajectory and Future Ahead. Journal of Political Issues. 3(1); 28-35. https://doi.org/10.33019/jpi.v3i 1.61

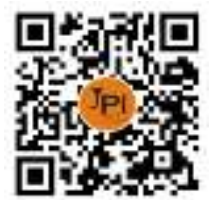

DOI:

https://doi.org/10.33019/jpi.v3i 1.61

Licence:

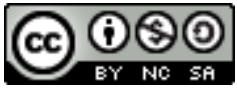

Attribution-NonCommercialShareAlike 4.0 International (CC- BY-NC-SA 4.0)

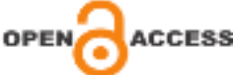

\begin{abstract}
Abstract: Mongolia's uniqueness and importance in contemporary world politics lie in its geographical situating, demography, and economy. Geographically landlocked and situated in the Eurasian intersection, Mongolia has the lowest population density of any sovereign country on the planet. Sandwiched among Russia and China Mongolia's harsh environment limit its economic interests. However, Mongolia's geostrategic position, unexplored energy assets, and democratic governance have expanded its importance in global politics. Because of such Mongolia holds a key position in India's Act East and Connect Central Policy to counter China's expansionist policies in NorthEast Asia. With regards to India-Mongolia relations, the two nations share a rich historical legacy. Tibetan Buddhism the most prevailing religion in Mongolia makes social linkages, Democracy solidified further connections between India and Mongolia. Because of these old and profoundly established linkages, India-Mongolia are 'spiritual neighbors'. However, China still has an overreaching control over Mongolia's trade, commerce, and other sectors. China also dominates intra-regional trade in North-East Asia. Under India's Connect Central Asia India attempts to counter Chinese encirclement by delving into close strategic, economic, and energy relations with China's neighbors like Mongolia and CAS. However, the achievement or failure of India's Connect Asia Policy will depend upon India's political as well as its diplomatic will to transform India's interest in regional integration in reality.
\end{abstract}

\section{About Authors:}

Dr. Subhash Kumar is currently working as an assistant professor in the Department of Politics and International Relations, Central University of Jharkhand, India. He did his M.Phil. \& Ph.D. from School of International Studies, Jawaharlal Nehru University, New Delhi. He has contributed numerous articles and book reviews in renowned national and International Journals. His areas of expertise are Foreign Policy of Mongolia, Central Asian Studies, India's Foreign Policy, Inner Asian Studies.

Souvik Chatterjee is currently working as a Junior Research Fellow in the Department of Politics and International Relations, Central University of Jharkhand, India. He obtained his Master Degree in Political Science from Kazi Nazrul University, India and stood first class first in 2018. His areas of interest are Foreign Policy of Mongolia, Political sociology, Comparative Politics, Inner Asian Studies. 


\section{INTRODUCTION}

Mongolia's uniqueness and importance in contemporary world politics lie in its geographical situating, demography, and economy. Geographically landlocked and situated in the Eurasian intersection, Mongolia has the lowest population density of any sovereign country on the planet. Sandwiched among Russia and China Mongolia's harsh environment limit its economic interests. However, Mongolia produces the world's best cashmere, has vast energy and mineral assets (Goodson \& Addleton, 2020). Mongolia's geostrategic position, unexplored energy assets, and democratic governance have expanded its importance in global politics. Because of such Mongolia holds a key position in India's Act East and Connect Central Policy to counter China's expansionist policies in North-East Asia.

Mongolia, after its democratization in the 1990s, has been resolved to transform itself as a landlocked to land-connected cosmopolitan (Bulag, 2010). Geographically, Mongolia is landlocked by Russia and China. During the rule of Chinggis Khan Mongolia expanded its reach from the eastern edge of Asia to the most distant parts of Europe. Due to this intermingling, Mongolia shares social, cultural linkages with other Central Asian States (CAS henceforth). After its autonomy in 1921 till 1991, Mongolia was a Soviet Satellite however officially it was never part of the USSR. However, since its democratic transformation in 1991, Mongolia focuses on a free-market economy and developing cordial relations with its neighbors and other major powers. Without the fundamental Soviet assistance, Mongolia looks for multilateral partnerships and alliances to sustain its domestic economy. Mongolia's Third Neighbor policy aims at balancing its relations with its two powerful neighbors, the Peoples' Republic of China and the Russian Federation while exploring financial, energy, and multilateral partnership with the USA, Japan, and Germany, India, Japan, the Republic of Korea, etc.

With regards to India-Mongolia relations, the two nations share a rich historical legacy. In spite of limited political and economic exchanges, the social and cultural aspects of their relationship are emphasized for ages. While Tibetan Buddhism the most prevailing religion in Mongolia makes social linkages, Democracy solidified further connections between the two. Indian monks visited and spread Buddhism in Mongolia in about the fifth Centuries A.D. Furthermore, there are additional linkages between India and Mongolia. Also linguistic affinity along with other affinities beginning from wrestling to clothing, there is a great degree of resemblance between the two (Nyamdavaa, 2003). Because of these old and profoundly established linkages, Prof. Oidov Nyamdeva named India-Mongolia as 'spiritual neighbors' (Nyamdavaa, 2015). The two nations are searching for deeper Strategic, Economic, and Energy cooperation which are given priority in India's Connect Asia Policy and Mongolia's Third Neighbors Policy. Mongolia since the 1990s attempts to extend its sphere of influence beyond Russia and China and accept India as an important strategic partner.

\section{OBJECTIVES OF THE STUDY}

India under its Connect Central Asia Policy is attempting to counter Chinese encirclement by delving into close strategic, economic, and energy relations with China's neighbors like Mongolia and CAS. Remembering these progressions in Indian Foreign policy this study will attempt to uncover the following objectives I. Challenges and difficulties in India's Connect Central Asia policy and II. The importance of Mongolia in India's Connect Central Asia policy and its implications in North-East Asian politics. 
Generally, foreign relations between nations require a systematic understanding of pertaining issues to understand the current direction and to comprehend the future potentiality of the relation. It requires a complete understanding of available sources. This study is an attempt to understand the significance of Mongolia in India's Connect Central Asia Policy using qualitative data. Existing works both primary and secondary sources along with eresources and news coverings on this issue are consulted extensively.

\section{RESULTS}

\section{Mongolia and The New Great Game}

Mongolia for a while was able to maintain its autonomy and established the largest empire under the dynamic and capable authority of Chinggis Khan. However, with the rising force of China's Qing dynasty, Mongolia became the part of Chinese empire from 1691 to 1911. Thereafter because of the Chinese oppressive treatment of Mongols, Mongolia looked for complete autonomy. Under the Treaty of Kyakhta in 1915 China for a short time recovered control of Mongolia yet with the help of the USSR, Mongolia removed the Chinese after the 1917 October Revolution (Goodson \& Addleton, 2020).

Before the end of the cold war, Mongolia stayed as a Soviet Satellite and depended heavily on financial assistance from the USSR (Rossabi, 2009). Also, the USSR assisted Mongolia to ousted the monarchy and set up communism in the country. Mongolia's geostrategic location helped it as a buffer state with China. So Mongolia during this time was not only dependent upon the USSR for monetary assistance, Mongolia's internal and external strategies were molded by the USSR.

The democratic transformation of Mongolia began with Gorbachev's Glasnost and Perestroika that affected Mongolia significantly. The democratization in Mongolia took off with Iltod and Orchilan Baigalalt (Krishna, 2017). Mongolia, unlike its neighbors, especially in Central Asia, is more internally stable and emerged as a regional beacon for democratic development in the region (Krishna, 2017). Because of Mongolia's democracy and its mineral wealth, Mongolia is drawing the attention of major powers to invest in its neglected energy sector. Nonetheless, Mongolia's two neighbors Russia and China are still dominating Mongolia's foreign policy, especially security and energy policies. The internal reforms alongside the changed geostrategic situation make it feasible for Mongolia to pursue realist foreign policy based on post-soviet public interests (Krishna, 2017). Mongolian Foreign Policy Blue Book (2000) by the Ministry of External Relations stressed favorable internal and external conditions to maintain Mongolia's national interests, along with financial development and ensure its national security (Policy Planning and Coordination Department 2000; Krishna, 2017). So diversity and geopolitics have forced Mongolia to adopt a multilateral foreign policy.

\section{Mongolia in The New World Order: From Soviet Satellite to Democratic Transformation}

Nonetheless, with the disintegration of the USSR, Mongolia experienced significant challenges. Mongolia for a while dependent upon on USSR for financial and security assistance. Almost 40\% of Mongolia's GDP, energy assets, most of its heavy machinery, and consumer goods were imported from the USSR (Goodson \& Addleton, 2020). With the collapse of the USSR, the Mongolian economy endured a dramatic loss. Also, the USSR for quite a while helped Mongolia to sway from Chinese animosity. Without the help of the 
USSR, China again claiming Mongolia as a part of its territory and there is a growing concern that Mongolia will endure a similar destiny such as Tibet and Taiwan.

Mongolia attempted to counter this with two specific policies each having its own geostrategic and economic objectives. Under the good neighbor policy, Mongolia began balancing its relationship with its two powerful neighbors Russia and China. Furthermore, under the ambit of the third neighbors' policy, Mongolia tries to foster more political, financial, and social exchanges with nations like the United States, Japan, South Korea, India, Australia, and so on. Lately, China's assertiveness over North-East Asia, particularly Mongolia, has expanded while the West is trying to use Mongolia as an ally to counter China. Mongolia's democracy, geopolitical positioning alongside its neglected immense energy assets are bringing fundamental changes in North Asian security.

\section{Beijing's Assertion in Mongolia and its Implications for India}

In recent times China has emerged as a global hegemon which is also evident in its complete control over North-East Asia and Mongolia specifically. Under the Belt Road Initiative(BRI) China is using infrastructure as leverage to further strategic and economic interests in Asia and Africa. (Goodson \& Addleton, 2020).

With the help of six transnational corridors, China plans to connect Eastern Europe via Mongolia and Russia (Goodson \& Addleton, 2020). These passages will create new mineral markets for Mongolia and help Mongolia to act as a North-East Asian logistic hub. In the post-cold war period, China's authority over Mongolia increased considerably. China isn't just financing costly infrastructures in Mongolia, yet in addition, China attempts to influence Mongolia's politics as well. As of late China dominates Mongolia's economy. The majority of Mongolia's minerals like copper, coal, and gold are traded to China while Mongolia is importing energy and other essential services from China. Because of this over-reliance on China, the Mongolian economy is profoundly helpless against Chinese economic fluctuations which prompted a meltdown in Mongolia's economy. Even though India and Western forces are creating economic tie-ups with Mongolia, China has an overextending command over Mongolia. China controls and dominates Mongolia's trade, commerce, and energy sector. China also has overriding control over intra-regional trade in North-East Asia including Mongolia. The complete trade volume between China and other North Eastern Countries in 2018 crossed 758 billion US \$ that demonstrates the Chinese supremacy in the region (Xia, 2019). In North-East Asia, the two most powerful countries, China and Japan, are focusing on Mongolia's neglected energy assets.

Japan is helping Mongolia in FDI's while the People's Republic of China is presently the largest trading partner of Mongolia. Nonetheless, because of the political unrest business and exchange exercises with China are enduring impressively. To counter this, China alongside other North-East Asian nations is setting up a multilateral forum to explore new possibilities in energy, business, and infrastructural improvement in the region. China is providing financial and strategic help to all its North East Asian neighbors as part of China's debt diplomacy. On opposite India and Western forces have limited interaction with Mongolia in the strategic, trade, and energy sector. As far Indo-Mongolian Bilateral Trade is concerned, trade potential was estimated at 8.45 billion U.S dollars but in reality, IndoMongolian bilateral trade was just 12.03 million US dollars in 2015 (De \& Pan, 2017). Mongolia's rich natural resources and minerals requires technical expertise and logistic support, here India can play a catalytic role. Under India's Act East Policy and Connect Central Asia Policy Mongolia occupy a key role to further India's interest in the Eastern part of Asia. Under the Central Asia policy, India intends to counter Chinese assertion in South Asia by strengthening its relations with Mongolia and extending its influence in Northeast Asia.

To influence Mongolia's Internal policies, China is utilizing Debt Diplomacy as a potent tool of Chinese foreign policy (Goodson \& Addleton, 2020). As Mongolia is 
dependent on China in trade and energy, China is utilizing this to influence Mongolia's decision-making process. For instance, at the onset of the Dalai Lama's visit in 2016 Chinese increased trade tariffs on Mongolian products as punishment. In this aspect, the role of Russia is very critical. Alongside China, Russia is another important player in the region and both Mongolia and Russia enjoys cordial relation. Both China and Russia's geostrategic interests are dependent upon Mongolia because of its role as a buffer state. Similarly, to counter the US both Russia and China are looking for a military alliance with the help of Mongolia. Just like China, Russia attempts to rebuild its economy and strategy with Mongolia. Russia dominates Mongolia primarily in energy as it supplies around 80\% of Mongolia's oil market, and bilateral trade has increased almost 40\% since 2017 (Goodson \& Addleton, 2020). Also, Russia is investing in a 1.5 billion \$ infrastructural project, along with the up-gradation of the trans-Mongolian railway, and use Mongolia as a route for the Russia-China gas line project.

\section{DISCUSSION}

\section{The Role of Mongolia in India's Connect Central Asia Policy}

Geologically, Central Asia conjuncts Islam, Buddhism, Christianity, and Hinduism the four dominant religious faith of the globe. Albeit Modern Central Asia comprises Kazakhstan, Kyrgyzstan, Tajikistan, Turkmenistan, and Uzbekistan, Mongolia is part of this because of overlapping of cultures and similar lifestyles. Also, these states were reliant upon the USSR and part of COMECON. India and Central Asia also share rich historical exchanges. The Ancient silk route and Indus valley civilization fostered cultural and social exchanges between the Indian subcontinent and Central Asia. Because of this India always considers Central Asia as a part of India's "extended neighborhood". However, with the decline of the USSR, China's supremacy in Central Asia increased significantly.

Additionally, due to the Afghan Civil War, India lost its direct overland access to Central Asia. Before the fall of the USSR, Soviet Union had total predominance over Central Asia. All of the Central Asian states were either part of it or acted as a satellite of the Red State like Mongolia. The Indo-Soviet Treaty of Peace in 1971, increased economic cooperation and strategic convergence between India and the Soviet Union, allowed India to augment its relations with the Central Asian States. Notwithstanding, with the fall of the USSR, Central Asia has become increasingly unstable and rigged with ethnic and separatist movements. India requires stability in Central Asia as it shares borders with Pakistan and Afghanistan.

Mongolia is significant in this aspect because it can act as a geographical pivot between Russian China while sharing a close affinity with the Central Asian region as well. India under its Connect Central Asia and Look North policy focusing on both Central Asia and Mongolia. Today India develops strategic and trade relations with Central Asia and Mongolia. Thus Connect Central Asia Policy focuses on deeper political, security, economic, and cultural interactions with CAS and lately Mongolia as well (Ahamed, 2012). Under this detailed approach, India focuses on many important areas including political cooperation, economic cooperation, strategic cooperation, regional connectivity, information technology (IT), cooperation in education, people-to-people contact, medical cooperation, and cooperation in regional groupings. With four key areas, Commerce, Connectivity, Consular, and Community, India is attempting to limit China's domination in the region and to ensure regional stability (Drishtiias.com,2019).

Changing geopolitical equations are part of Connect Central Asia policy as this region is strategically positioned as an access point between Europe and Asia. Moreover, both Central Asia and Mongolia are richly endowed with natural gas, cotton, gold, copper, 
aluminum, and iron. The expanding significance of energy security of the region's oil and gas resources has compelled India to develop more ties with Mongolia and CAS. India under this approach negotiated on the TAPI pipeline along with signing a civil nuclear deal with Kazakhstan. India is also focusing on (Drishtiias.com, 2019). Both CAS and Mongolia require India's expertise in these sectors and deeper strategic cooperation will give a fresh impetus to trade relations with these countries. To convince the Central Asian States, the Indian PM visited all 5 central Asian countries and Mongolia called for greater participation in multilateral fora like the Eurasian Economic Union, Heart of Asia Conference, and Shanghai Cooperation Organisation.

Because of the landlocked positioning of Central Asian states and Mongolia, there is no direct sea route that impacts India's trade and energy interests in the region. With the Belt and Road Initiatives China is required to increase its dominance in the Central Asian republics and Mongolia in terms of investments within the region. Likewise, Russia and China's convergence in Mongolia has changed the dynamics of India's relations with Central Asia. Mongolia has ample natural assets like oil, gold, silver, iron, coal, etc. However, due to the absence of skill and troublesome environment

Mongolia's energy resources remained unexplored. In light of this Indian Government is keen on different geostrategic and mining projects in Mongolia. Alongside a joint military exercise, in 2015 India gave 1 billion dollars' line of credit to Mongolia to construct its firstever oil refinery followed by a high-level visit by Smt. Sushma Swaraj. In recent times there have been several high-level visits such as PM Modi's historical visit to Mongolia in 2015 followed by Mongolian President Khaltmaagiin Battulga's visit to India to discuss trade and investment potentials in the Mongolian energy sector. India is likewise in talks with Mongolia to have more prominent collaboration in the hydrocarbons and steel sector. During a virtual meeting, Indian Minister Pradhan praised leadership for their speedy approvals on the pending green field Mongol Refinery Project, built under a Line of Credit from the Government of India which is expected to complete by 2022 (The Hindu Business Line, 2021).

Nonetheless, China still maintains its hegemonic position both in Mongolia and Central Asia. Chinese supreme monopoly can be observed in trade, commerce, and energy sectors. Both the Western Powers and China are exploring the energy potentials of Mongolia and that's why they are investing in the energy sector. China, to expand its control, is interested in a multilateral dialogue between Mongolia and CAS regarding energy, trade, and infrastructural development in the region. Then again, despite historical and cultural linkages with the region, India's interaction in economic and energy sectors remains minimal. Mongolia's energy strategy is to a great extent dictated by its nearby neighbors, particularly China. Under India's Act East Policy and Central Asia Policy, India attempts to increase its presence in the further Eastern region of Asia. While India is in steady danger of Chinese encirclement policy in South Asia, India was not able to expand its influence beyond its immediate neighbors. Here Mongolia is going act as an influential player in the northeastern regional cooperation.

\section{CONCLUSION}

In India's Connect Central Asia policy Mongolia holds a focal position both from a geostrategic point of view and from economic and energy avenues in the region. Mongolia's position connecting Central Asia, North East Asia, Far East Asia is attracting India to develop more ties. (Stobdan, 2015). Mongolia's closeness with CAS and with China reinforces Mongolia's geo-strategic importance. The Indian government has focused on India's old age historical ties with Mongolia such as Buddhism and India's active role in the promotion of democracy in the region. India is expected to import rich minerals such as Uranium from 
Mongolia while investing in infrastructure setup in Mongolia. India's active role in the nonaligned movement, the reputation of being the largest democracy, and the principle of nonintervention greatly attract Mongolia's foreign policymakers. Also, public inclinations developed against China in Mongolia due to its long history of suppressing and opposing residents of Inner Mongolia. Due to this India occupies a central position in Mongolian foreign policy discourse to counter China and Russia. Mongolia's transformation to democracy, its foreign, as well as domestic policy, was guided and molded by USSR but in recent times China's influence in the region is so intense and far-reaching, many people fear the loss of Mongolia's autonomy to China once again (Stobdan, 2015). India is very much aware of Mongolia and CAS's significance as a geopolitical pivot but at the same time, both Mongolia and India are partnering with each other like engaging in defense as well as strategic tie-up, policymaking to strengthen their partnership. However, the achievement or failure of India's Connect Asia Policy will depend upon India's political as well as its diplomatic will to transform India's interest in regional integration in reality.

\section{FUNDING}

This Study received no specific grant from any funding agency in the public, commercial or not for profit sectors.

\section{CONFLICTS OF INTERESTS:}

The authors have declared no competing interests exist.

\section{REFERENCES}

Ahamed, M. S. (2012, June 12). Keynote Address at First India-Central Asia Dialogue on India's 'Connect Central Asia' Policy at India's 'Connect Central Asia' Policy. Ministry of Indian External Affairs Retrieved May 10, 2021 from https://www.mea.gov.in/Speeches-Statements.htm?dtl/19791/

Bulag, U. E. (2010). Mongolia in 2009: From Landlocked to Land- linked Cosmopolitan. Asian Survey, 50(1), 97-103. https://doi.org/10.1525/as.2010.50.1.9

Drishtiias.com. (2019). Connect Central Asia Policy. Drishti IAS. https://www.drishtiias.com/to-the-points/Paper2/connect-central-asia-policy

De, P., \& Pan, S. (2017, October). India-Mongolia Economic Relations: Current Status and Future Prospect. The Northeast Asian Economic Review, 5(2), 31-47. https://ideas.repec.org/a/eri/review/5231-47.html

Goodson, J., \& Addleton, J. (2020, January 29). How Great Power Competition Is Changing the Geopolitics of Mongolia. Retrieved from RealClear Defense: https://www.realcleardefense.com/articles/2020/01/29/how_great_power_competition_i s_changing_the_geopolitics_of_mongolia_115003.html

Krishna, V. (2017). Mongolia's Foreign Policy: Profiling Fundamental Aspects. International Journal of Applied Social Science, 4(9-10), 402-414. 
http://scientificresearchjournal.com/wp-content/plugins/downloadattachments/includes/download.php?id=2569

Policy Planning and Coordination Department (2000). Mongolian Foreign Policy Blue Book., Ministry of External Relations. http://www.qingis.com/photos/foreign\%20blue\%20book\%20eng.pdf

Nyamdavaa, O. (2003). Mongolia-India relations. New Delhi: Bhavana Books \& Prints.

Nyamdavaa, O. (2015). Ancient Cultural, Ethnic and Religious Ties Between Mongolia and India. World Affairs: The Journal of International Issues, 19(4), 150-159. https://www.jstor.org/stable/48505253

Rossabi, M. (2009). Modern Mongolia from Khans to Commissars to Capitalists. Berkeley, CA: Univ. of California Press.

Stobdan, P. (2015, May 13). India and Mongolia: Modi on Ashoka's Path. Retrieved December 2019, 20 from Institute for Defence Studies and Analyses: https://idsa.in/idsacomments/IndiaandMongolia_pstobdan_130515

The Hindu BusinessLine. (2021, January 08). India, Mongolia review bilateral cooperation in hydrocarbons and steel sectors. Retrieved 15 February, 2021 from The Hindu BusinessLine: https://www.thehindubusinessline.com/economy/policy/india-mongoliareview-bilateral-cooperation-in-hydrocarbons-and-steel-sectors/article33530455.ece

Xia, L. (2019). China Focus: Northeast Asian countries eye closer ties to boost global economy. Retrieved December 2019, 19 from Xinhuanet: http://www.xinhuanet.com/english/2019-08/27/c_138342481.htm 